\title{
KARAKTERISTIK ANTRIAN KAPAL DAN FAKTOR-FAKTOR YANG MEMPENGARUHI WAKTU TUNGGU KAPAL (WAITING TIME) DI PELABUHAN TANJUNG PERAK
}

\author{
Frizky Andrian Perdana ${ }^{* 1}$, Alwafi Pujiraharjo ${ }^{2}$, Indradi Wijatmiko ${ }^{3}$ \\ ${ }^{1}$ Mahasiswa, Program Magister, Jurusan Teknik Sipil, Fakultas Teknik, \\ Universitas Brawijaya \\ ${ }^{2}$ Dosen, Jurusan Teknik Sipil, Fakultas Teknik, Universitas Brawijaya \\ ${ }^{3}$ Dosen, Jurusan Teknik Sipil, Fakultas Teknik, Universitas Brawijaya \\ Korespondensi: andrianfrizky43@gmail.com
}

\begin{abstract}
Economic growth in Indonesia especially in East Java and Eastern Indonesia has caused the number of ship visits in Tanjung Perak Port to increase. These conditions resulted in a higher ship queue that will linearly cause the waiting time of the ship (waiting time) in the port which is getting longer. Therefore it is necessary to study about the average of ship waiting time, the characteristics of ship queue, the factors that affect the waiting time of the ship, the direction of improvement. This study uses the Queue Analysis Method, Multiple Regression Analysis and SWOT Analysis. The analysis shows that the average waiting time at Tanjung Perak Harbor is the longest in the northern and western emerald terminal of 46.20 hours, and the smallest is in the diamond terminal 29.94 hours and the terminal of 29, 94 hours. From queuing characteristics, the percentage of server usage of northern and western emerald terminal terminal has exceeded the capacity of 124.44\%, while the southern emerald terminal is $94.40 \%$, Diamond Terminal is $70.56 \%$, Multipurpose Terminal is $84.31 \%$, and Mirah terminal $85.24 \%$, From the simulation of North and West Jamrud Terminal requires at least 7 servers. The most influential factor on (waiting time) is the Availability of Pier (X4) of 13.25\% and then the effect of the Production of Loading and Unloading (X1) of $12.11 \%$ with the regression model obtained is $Y=403.914-8.198$ X1-6.551X2-4,874 X3-6,409 X4-6,909 X5. The Strategy must be done to decrease the waiting time of ships at Tanjung Perak Port by maximizing the performance of the loading and unloading force (TKBM), transferring the vessel to dock at the surrounding ports such as Lamong Bay Terminal and Manyar BMS Gresik Terminal and improving services and document processing procedures at the port to cope with the increase in the flow of goods. Developing Surabaya's West Sailing Channel (APBS) to revitalize the Sailing Flow and harbor pools, implement correct port regulation and maximize existing guidance to anticipate the increase in ship visits.
\end{abstract}

Keywords: Ship Wait Time, Queue, Multiple Linear Regression, SWOT

\section{PENDAHULUAN}

Pelabuhan merupakan pintu gerbang untuk masuk ke suatu daerah tertentu dan sebagai prasarana penghubung antar daerah, antar pulau, bahkan antar negara. Pelabuhan berperan sebagai terminal yang mempertemukan moda transportasi baik intermodal maupun multimodal, mendorong lancarnya transaksi perdagangan serta perindustrian bagi pembangunan ekonomi [1].

Pertumbuhan sektor industri di Jawa Timur dan Indonesia Bagian Timur telah menyebabkan jumlah kunjungan kapal di
Pelabuhan Tanjung Perak menjadi meningkat, sehingga aktivitas bongkar muat barang di Pelabuhan Tanjung Perak juga menjadi meningkat. Dengan kondisi sarana dan prasarana yang tetap serta seringkali tidak disertai pengoptimalan kinerja pelabuhan, tentunya hal tersebut berpotensi menimbulkan antrian kapal untuk sandar di Pelabuhan Tanjung Perak sehingga menimbulkan waktu tunggu kapal semakin besar akibatnya kinerja Pelabuhan kurang optimal yang akan menimbulkan biaya ekonomi yang tinggi, yang akan berdampak langsung dengan harga barang 
di pasaran. Seperti banyak diketahui bahwa biaya logistik terbesar di Indonesia ada di pelabuhan dan menjadi permasalahan nasional.

Dari uraian diatas, maka yang menjadi permasalahan dalam penelitian ini adalah:

1. Berapa rata-rata waktu tunggu kapal (waiting time) di Pelabuhan Tanjung Perak Surabaya?

2. Bagaimana karakteristik antrian kapal di Pelabuhan Tanjung Perak Surabaya dilihat dari tingkat kedatangan dan tingkat pelayanan?

3. Faktor-faktor apakah yang mempengaruhi waktu tunggu (waiting time) kapaldi Pelabuhan Tanjung Perak?

4. Bagaimana rekomendasi perbaikan untuk menurunkan waktu tunggu kapal (waiting time) di Pelabuhan Tanjung Perak?

Pembatasan masalah lingkup penelitian pada penelitian ini adalah:

1. Studi, penelitian dan pengambilan data hanya pada lingkup pelabuhan Tanjung Perak Surabaya di 4 (empat) terminal yaitu Terminal Jamrud, Terminal Berlian, Terminal Mirah, dan Terminal Nilam (Multipurpose).

2. Lingkup penelitian meliputi pelayanan kapal dan utilisasi fasilitas. Pengamatan dilakukan terhadap jenis dan ukuran kapal yang bersandar di dermaga atau pelabuhan meliputi: Kapal Petikemas, Kapal General Cargo (non Petikemas), Kapal Curah Kering dan Kapal Curah Cair.

3. Ukuran Kapal atau bobot mati kapal yang termasuk dalam penelitian adalah Kapal Petikemas, Kapal General Cargo (Non Petikemas), Kapal Curah Kering dan Kapal Curah Cair dengan bobot mati mulai dari GT 500.

4. Metode yang digunakan adalah metode Analisis Model Antrian, Analisis Regresi Linear Berganda dan Analisis SWOT.

\section{METODE PENELITIAN}

\subsection{Tahapan Penelitian}

Adapun tahapan-tahapan yang dilaksanakan dalam penelitian dapat dilihat pada

Gambar 1.

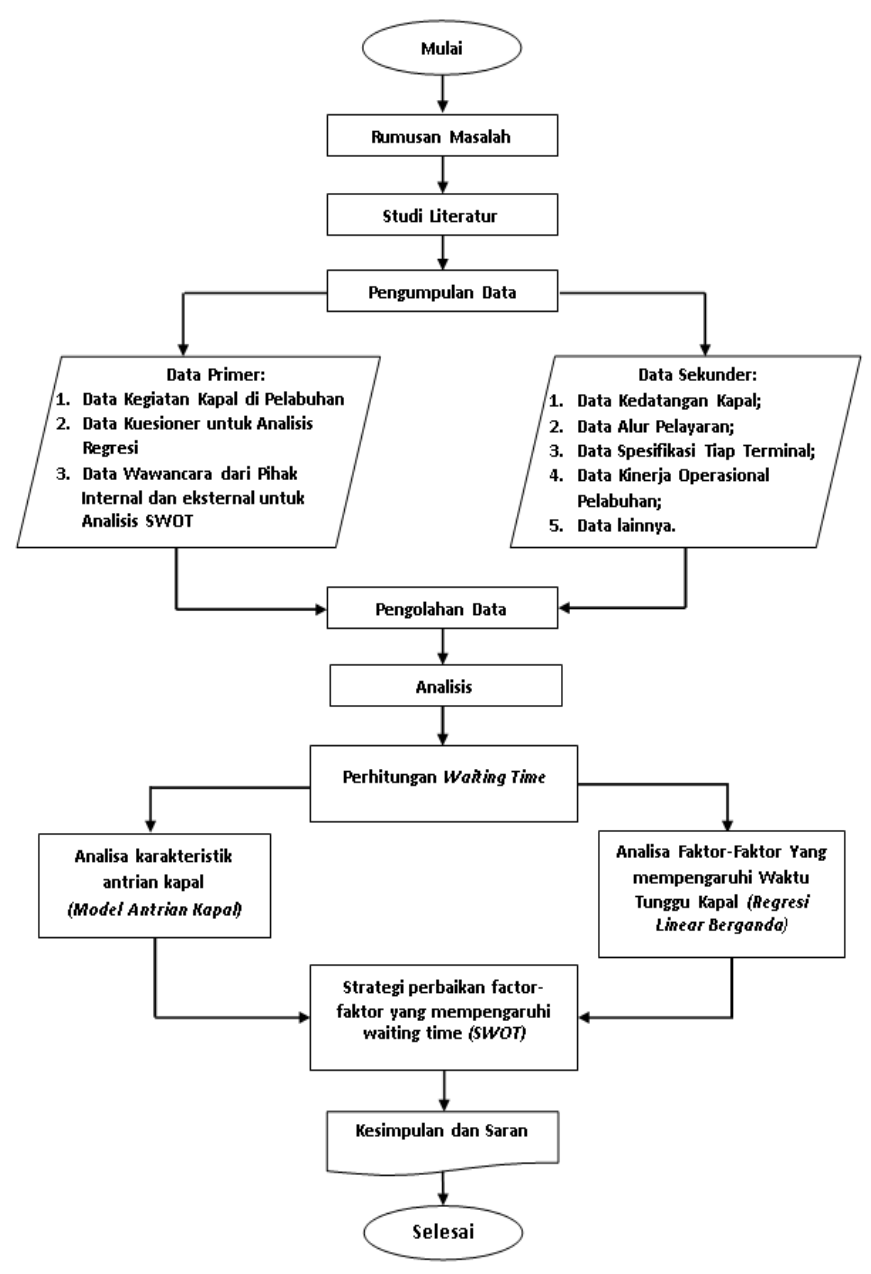

Gambar 1. Diagram alir penelitian

\subsection{Metode Analisis Data}

Metode analisis yang digunakan data dalam penelitian ini antara lain:

1. Analisis Antrian

Analisis Antrian digunakan untuk mengetahui karakteristik antrian di Pelabuhan Tanjung Perak Pengamatan dilakukan untuk mendapatkan data jumlah kedatangan kapal, waktu kedatangan kapal, dan waktu pelayanan kapal di pelabuhan yaitu dengan cara: 
a. Pengambilan sampel data dilakukan selama 1 (satu) bulan sesuai dengan penetapan kedatangan dan pelayanan kapal dari Kantor Otoritas Pelabuhan Utama Tanjung Perak.

b. Pengamatan dilakukan berdasarkan jenis dan tipe kapal dari tiap-tiap terminal yang menggunakan jasa Pelabuhan Tanjung Perak.

Asumsi-asumsi yang digunakan dalam analisis antrian antara lain:

a. Disiplin antrian First Come First Service dengan menggunakan model antrian Multi Channel Single Phase

b. Waktu antar kedatangan mengikuti distribusi poisson

c. Waktu antar pelayanan mengikuti distribusi eksponensial

d. Sumber masukan tidak terbatas dan ukuran antrian tidak terbatas.

2. Analisis Regresi Berganda

Analisis Regresi Berganda digunakan untuk memperoleh faktor-faktor yang mempengaruhi waktu tunggu kapal (waiting time) di Pelabuhan Tanjung Perak. Dalam analisis ini menggunakan data primer yang didapatkan dari kuesioner dari pengguna jasa Pelabuhan Tanjung Perak yaitu perusahaan pelayaran yang penentuan sampelnya dihitung menggunakan rumus Slovin: [5]

$n=\frac{N}{1+N e^{2}}$

Dimana:

$\mathrm{n}=$ ukuran sampel

$\mathrm{N}=$ ukuran populasi

$\mathrm{e}=$ perkiraan tingkat kesalahan $(10 \%=0,1)$

maka :

$n=\frac{391}{1+391(0,1)^{2}}=79,63 \approx \mathbf{8 0}$ Responden

\section{Analisis SWOT}

Untuk menentukan strategi perbaikan guna menurunkan waktu tunggu kapal (waiting time) di pelabuhan tanjung perak dengan menganalisa faktor-faktor strategi internal dan eksternal. Kemudian dilakukan wawancara dan pembagian kuesioner terhadap responden dianggap faham mengenai kondisi dan rencana pengembangan Pelabuhan Tanjung Perak.
3 HASIL DAN PEMBAHASAN

3.1 Rata-Rata Waktu Tunggu Kapal (Waiting Time) di Pelabuhan Tanjung Perak

Berdasarkan Surat Keputusan Dirjen Perhubungan Laut Nomor: UM.002/38/18/DJPL-11 Tahun 2011 tentang Standar Kinerja Operasional Pelabuhan disebutkan bahwa Waktu Tunggu Kapal (waiting time) adalah jumlah waktu sejak pengajuan permohonan tambat setelah kapal tiba di lokasi labuh sampai kapal digerakkan menuju tambatan sampai dengan tiba di tambatan.

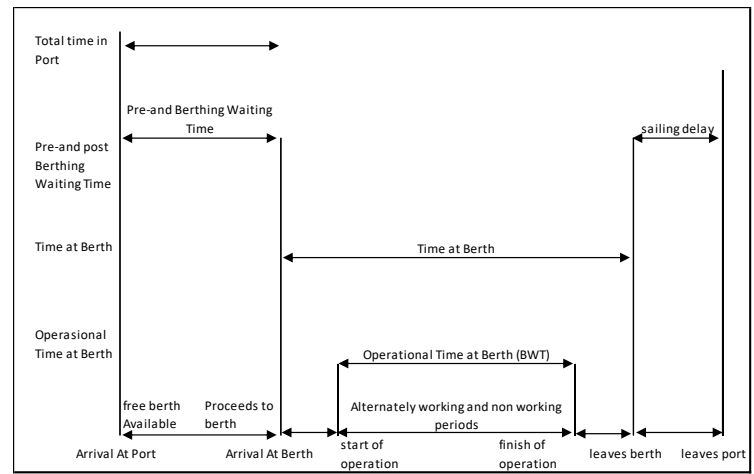

Sumber : (PT. Pelabuhan Indonesia (Persero), 2009)

Gambar 2. Skema waktu kapal selama di pelabuhan

Pada penelitian ini peneliti melakukan perhitungan dari data sekunder yaitu data penetapan kapal yang telah disahkan oleh Otoritas Pelabuhan Tanjung Perak selama 1 (satu) bulan yaitu pada bulan Januari 2016, kemudian peneliti membagi pada 5 (lima) terminal yang ada di Pelabuhan Tanjung Perak. Untuk menghitung waktu tunggu kapal menggunakan Persamaan 2 dibawah ini:

$W T_{i}=$ Waktu Sandar $_{i}-$ Waktu Minta Pelayanan $_{i}$

Di mana i menunjukkan nomor kapal, jadi untuk menghitung rata-rata waktu tunggu kapal (waiting time) dipelabuhan tanjung perak menggunakan Persamaan 3 berikut:

$\overline{W T}=\frac{\sum_{i=1}^{n} \text { Waktu Sandar }_{i}-\text { Waktu Minta Pelayanan }_{i}}{n}$

Di mana

$\overline{W T}$ : rata-rata waktu tunggu

$\mathrm{n}$ : banyak kapal 
Hasil perhitungan rata-rata waktu tunggu kapal dari 5 (lima) terminal Pelabuhan Tanjung Perak dapat dilihat pada Gambar 3.

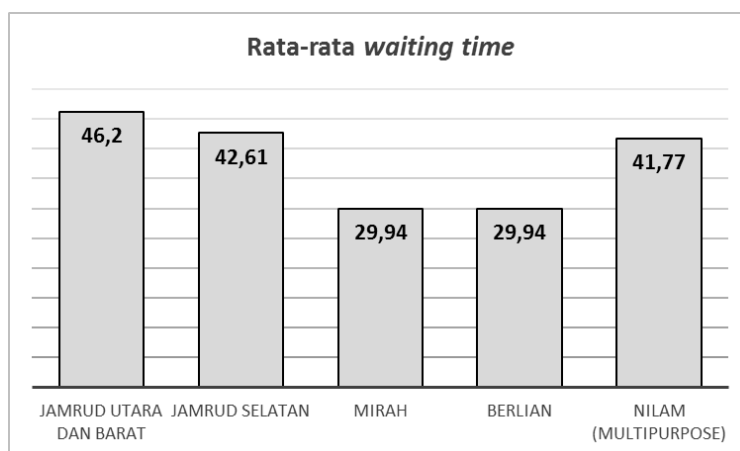

Gambar 3. Grafik rata-rata waktu tunggu kapal (waiting time) Pelabuhan Tanjung Perak

Dari Gambar 3 diketahui waktu tunggu (waiting time) rata-rata tertinggi berada pada Terminal Jamrud khususnya dermaga Jamrud Utara dan Barat yaitu sebesar 46,20 Jam atau 1,92 hari kapal menunggu untuk mendapat pelayanan.

\subsection{Karakteristik Antrian Kapal}

Kondisi eksisting Pelabuhan Tanjung Perak terbagi dalam beberapa terminal dimana penelitian difokuskan kepada 4 (empat) antara lain: Terminal Jamrud dibagi menjadi 2 terminal yaitu Terminal Jamrud Utara dan Barat yang diperuntukkan untuk melayani bongkar dan muat general cargo internasional, Terminal Jamrud Selatan dapat dikatakan terminal multipurpose karena peruntukkannya melayani bongkar dan muat general cargo dan kontainer domestik. Terminal Mirah yang melayani general cargo domestik dan kontainer domestik, Terminal Berlian untuk kontainer domestik dan Terminal Nilam (Multipurpose) bongkar dan muat curah cair dan general cargo domestik.

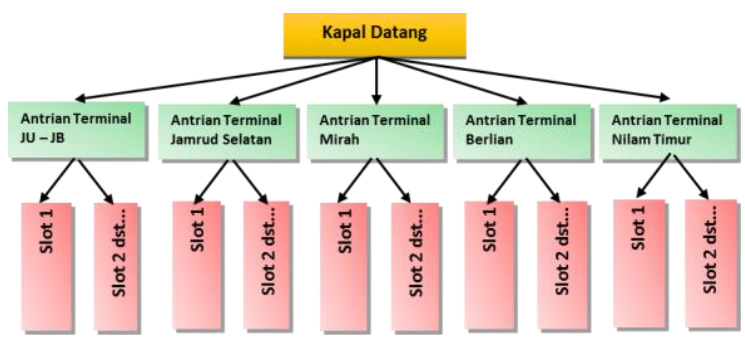

Gambar 4. Skema kedatangan kapal yang akan sandar di dermaga Pelabuhan Tanjung Perak
Alur analisis antrian di Pelabuhan Tanjung Perak terdiri dari tahapan pra analisis, tahapan uji kesesuaian probabilitas distribusi dan tahapan analisis.

1) Menduga Banyak Server $(M)$

Banyaknya server dihitung dengan asumsi memanfaatkan panjang dermaga yang ada di Pelabuhan Tanjung Perak dan rata-rata untuk panjang kapal dengan persamaan :

$$
M=\text { rounddown }\left(\frac{\text { panjang dermaga }}{\text { rata-rata panjang kapal }+ \text { Jagaan }}\right)
$$

Tabel 1. Jumlah server

\begin{tabular}{l|rrrr}
\hline Nama Dermaga & $\begin{array}{c}\text { Panjang } \\
\text { Dermaga } \\
(\mathbf{m})\end{array}$ & $\begin{array}{c}\text { Rata-rata } \\
\text { Panjang } \\
\text { Kapal (m) }\end{array}$ & $\begin{array}{c}\text { Jagaan } \\
\text { meter }\end{array}$ & $\begin{array}{c}\text { Banyak } \\
\text { Server } \\
\text { (unit) }\end{array}$ \\
\hline $\begin{array}{l}\text { Jamrud Utara \& } \\
\text { Barat }\end{array}$ & $800+210$ & 163,063 & 173,063 & $\mathbf{5}$ \\
\hline Jamrud Selatan & 800 & 97,400 & 107,400 & $\mathbf{7}$ \\
\hline Berlian & $785+700+$ & 112,414 & 122,414 & $\mathbf{1 2}$ \\
\hline Nilam Timur & $210+310$ & 84,542 & 94,542 & $\mathbf{5}$ \\
\hline Mirah & $312+338$ & 99,140 & 109,140 & $\mathbf{5}$ \\
\hline
\end{tabular}

2) Arrival Rate $(\lambda)$

Arrival rate merupakan rata-rata dari banyak kapal yang datang (k) per hari. Data diperoleh dari observasi yang dilakukan dari tanggal 2612-2015 s/d 28-1-2016 atau 34 hari. Arrival Rate $(\lambda)$ dapat dihitung dengan cara sebagai berikut:

$\lambda=\frac{k_{\text {haripertama }}+\cdots+k_{\text {hari terakhir }}}{\text { banyak hari }}$

Data yang diperoleh dihitung menggunakan persamaan diatas maka diperoleh nilai Arrival Rate $(\lambda)$ dari masing-masing dermaga dapat dilihat pada Tabel 2.

Tabel 2. Arrival rate $(\lambda)$ untuk masing-masing dermaga

\begin{tabular}{l|ccc}
\hline Nama Dermaga & $\begin{array}{c}\text { Jumlah } \\
\text { Kedatangan } \\
\text { Kapal Perhari } \\
\text { (Unit) }\end{array}$ & $\begin{array}{c}\text { Jumlah } \\
\text { (Hari) }\end{array}$ & $\begin{array}{c}\text { Rata-rata } \\
\text { Kedatangan } \\
\text { Kapal / Hari } \\
\text { (Unit) }\end{array}$ \\
\hline Jamrud Utara Barat & 64 & 34 & $\mathbf{1 . 8 8 2}$ \\
\hline Jamrud Selatan & 100 & 34 & $\mathbf{2 . 9 4 1}$ \\
\hline Berlian & 239 & 34 & $\mathbf{7 . 0 2 9}$ \\
\hline Nilam Timur & 59 & 34 & $\mathbf{1 . 7 3 5}$ \\
\hline Mirah & 87 & 34 & $\mathbf{2 . 5 5 9}$ \\
\hline
\end{tabular}

3) Service Rate $(\mu)$

Service Rate $(\mu)$ merupakan rata-rata pelayanan kapal per hari. Lama pelayanan untuk 
masing-masing kapal didapatkan dengan rumus sebagai berikut:

$\Omega=\frac{\sum_{k=1}^{n} \text { Waktu Berangkat }_{k}-\text { Waktu Sandar }_{k}}{n}$

di mana:

$k$ : no urut kapal

$n$ : banyak kapal yang mendapatkan pelayanan saat observasi

Setelah didapatkan Rata-rata Lama Pelayanan Kapal $(\Omega)$ maka dapat dicari nilai Service Rate $(\mu)$ dengan rumus sebagai berikut: $\mu=\frac{1}{\Omega}$

Tabel 3. Rata-rata lama pelayanan kapal $(\Omega)$ dan Service Rate $(\mu)$

\begin{tabular}{l|rr}
\hline Nama Dermaga & $\begin{array}{r}\text { Rata-rata waktu } \\
\text { pelayanan / kapal } \\
\text { (Hari) }\end{array}$ & $\begin{array}{r}\text { Service Rate }(\boldsymbol{\mu}) \\
\text { (Unit) }\end{array}$ \\
\hline Jamrud Utara Barat & 3.305 & $\mathbf{0 . 3 0 3}$ \\
\hline Jamrud Selatan & 2.247 & $\mathbf{0 . 4 4 5}$ \\
\hline Berlian & 1.205 & $\mathbf{0 . 8 3 0}$ \\
\hline Nilam Timur & 2.429 & $\mathbf{0 . 4 1 2}$ \\
\hline
\end{tabular}

Mirah 1

1.666 0.600

4) Tahapan Uji Kesesuaian Probabilitas Distribusi Poisson Kedatangan Kapal Untuk menghitung peluang kedatangan kapal per hari digunakan persamaan sebagai berikut: (Zaiontz, 2014)

$P(x)=\frac{e^{-\lambda} \lambda^{x}}{x !}$, untuk $x=0,1,2,3,4, \ldots$

di mana

$P(x)=$ peluang kedatangan $x \mathrm{kapal} / \mathrm{hari}$

$x \quad=$ banyaknya kedatangan kapal/hari

$\lambda=$ rata-rata kedatangan $\mathrm{kapal} / \mathrm{hari}$ e $\quad=2.7183$

Hasil distribusi poisson masing-masing dermaga ditampilkan secara grafik pada Gambar 5.

5) Uji Distribusi Eksponensial Pelayanan Kapal Uji eksponensial untuk waktu pelayanan dilakukan dengan menggunakan persamaan sebagai berikut: [2]

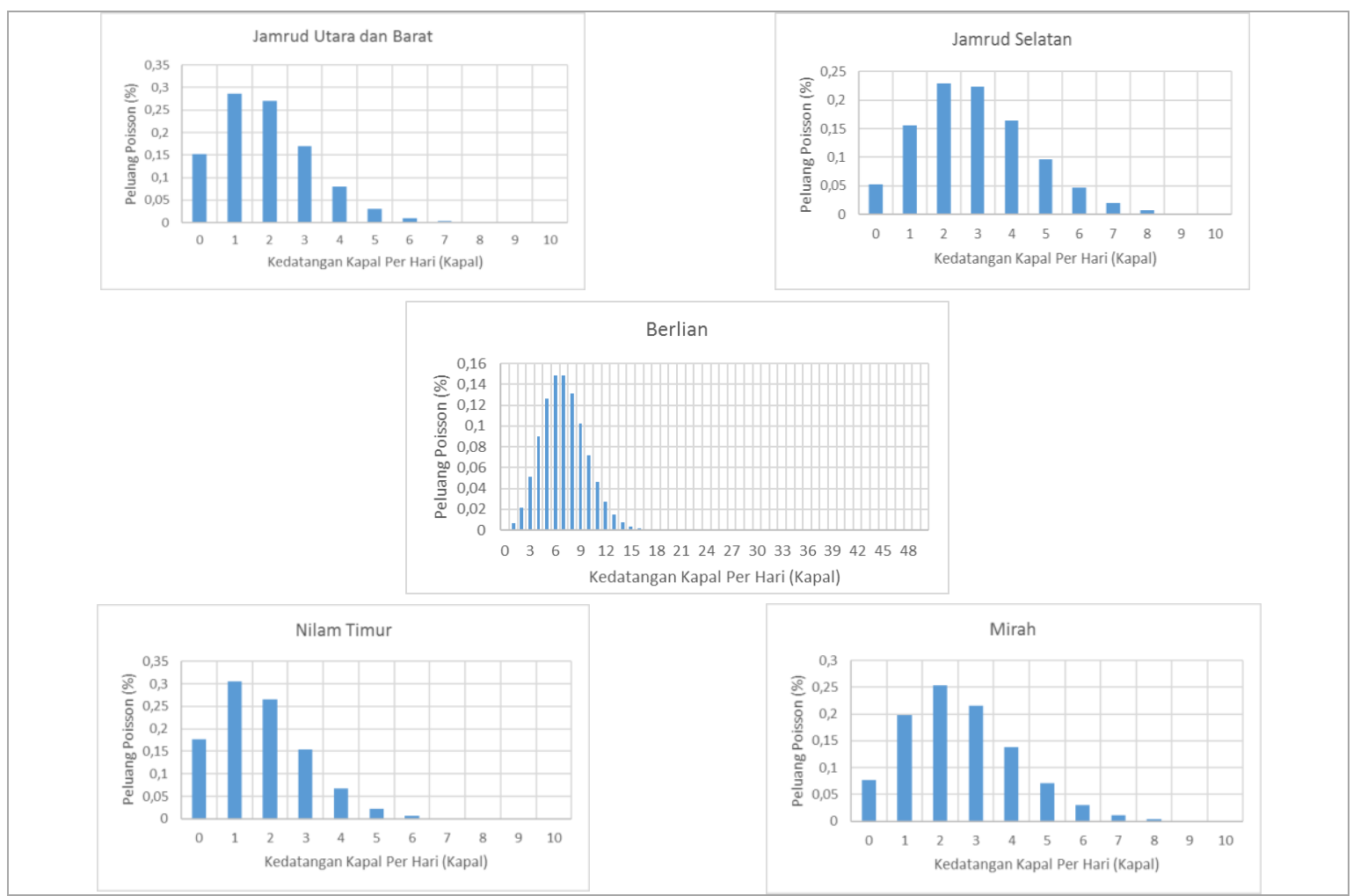

Gambar 5. Grafik peluang kedatangan kapal per hari

$P(t)=\lambda e^{-\lambda t}$, untuk $x \geq 0$

di mana:

$P(t)=$ peluang waktu pelayanan lebih dari $\mathrm{t}$

$t \quad=$ waktu pelayanan

$\lambda \quad=$ rata-rata waktu pelayanan e $\quad=2.7183$

Hasil distribusi eksponensial dari masingmasing dermaga yang ditampilkan secara grafik pada Gambar 6. 


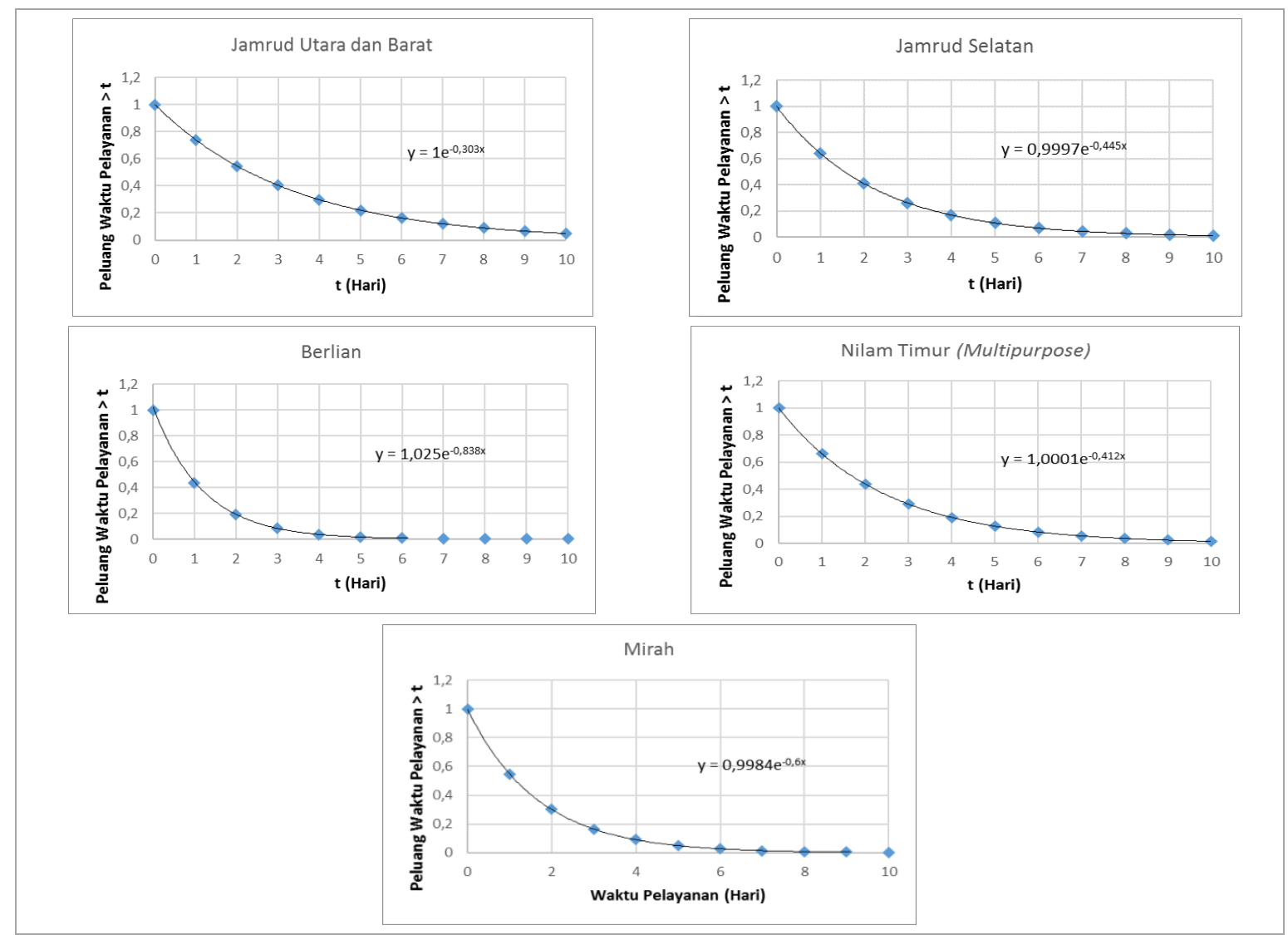

Gambar 6. Grafik peluang pelayanan kapal per hari

6) Server Utilization $(\rho)$ merupakan persentase penggunaan server menggunakan persamaan:

$\rho=\frac{\lambda}{M \mu}$

Dimana :

$\mathrm{M}=$ jumlah saluran pelayanan (channel)

$\mu=$ tingkat layanan rata-rata di setiap (channel)

$\lambda=$ rata-rata tingkat kedatangan

Hasil dari perhitungan prosentase penggunaan server $(\rho)$ didapatkan untuk masing-masing dermaga dapat dilihat pada Tabel 4.

Tabel 4. Persentase penggunaan server

\begin{tabular}{l|cccc}
\hline Nama Dermaga & $\begin{array}{c}\text { Arrival } \\
\text { Rate } \\
(\boldsymbol{\lambda})\end{array}$ & $\begin{array}{c}\text { Server } \\
(\mathbf{M})\end{array}$ & $\begin{array}{c}\text { Service } \\
\text { Rate } \\
(\boldsymbol{\mu})\end{array}$ & $\begin{array}{c}\text { Server } \\
\text { Utilization } \\
(\boldsymbol{\rho})\end{array}$ \\
\hline $\begin{array}{l}\text { Jamrud Utara dan } \\
\text { Barat }\end{array}$ & 1.882 & 5 & 0.303 & $\mathbf{1 2 4 . 4 4 \%}$ \\
\hline Jamrud Selatan & 2.941 & 7 & 0.445 & $\mathbf{9 4 . 4 1 \%}$ \\
\hline Berlian & 7.029 & 12 & 0.830 & $\mathbf{7 0 . 5 7 \%}$ \\
\hline $\begin{array}{l}\text { Nilam Timur } \\
\text { (Multipurpose) }\end{array}$ & 1.735 & 5 & 0.412 & $\mathbf{8 4 . 2 2 \%}$ \\
\hline Mirah & 2.559 & 5 & 0.600 & $\mathbf{8 5 . 3 0 \%}$ \\
\hline
\end{tabular}

7) Peluang tidak terdapat satupun kapal dalam system menggunakan persamaan: [2]

$$
P_{0}=\frac{1}{\left[\sum_{n=0}^{M-1} \frac{1}{n !}\left(\frac{\lambda}{\mu}\right)^{n}\right]+\frac{1}{M !}\left(\frac{\lambda}{\mu}\right)^{n} \frac{M \mu}{M \mu-\lambda}} \text {, untuk } M \mu>
$$

Pada Terminal Jamrud Utara dan Barat tidak dapat di analisis ke tahap selanjutnya karena nilai $M \mu \leq \lambda$. Berikut hasil analisis dapat dilihat pada Tabel 5.

Tabel 5. Peluang tidak terdapat satupun kapal dalam system $\left(\boldsymbol{P}_{\mathbf{0}}\right)$

\begin{tabular}{l|cccc}
\hline Nama Dermaga & $\begin{array}{c}\text { Arrival Rate } \\
(\boldsymbol{\lambda})\end{array}$ & $\begin{array}{c}\text { Server } \\
(\mathbf{M})\end{array}$ & $\begin{array}{c}\text { Service } \\
\text { Rate } \\
(\boldsymbol{\mu})\end{array}$ & $\left(\mathbf{P}_{\mathbf{0}}\right)$ \\
\hline $\begin{array}{l}\text { Jamrud Utara dan } \\
\text { Barat }\end{array}$ & 1.882 & 5 & 0.303 & - \\
\hline Jamrud Selatan & 2.941 & 7 & 0.445 & $\mathbf{0 . 0 4 \%}$ \\
\hline Berlian & 7.029 & 12 & 0.830 & $\mathbf{0 . 0 2 \%}$ \\
\hline $\begin{array}{l}\text { Nilam Timur } \\
\text { (Multipurpose) }\end{array}$ & 1.735 & 5 & 0.412 & $\mathbf{0 . 9 1 \%}$ \\
\hline Mirah & 2.559 & 5 & 0.600 & $\mathbf{0 . 8 3 \%}$ \\
\hline
\end{tabular}


8) Rata-rata banyaknya kapal dalam system menggunakan persamaan: (Heyzer \& Render, 2009)

$$
L_{s}=\frac{\lambda \mu(\lambda / \mu)^{M}}{(M-1) !(M \mu-\lambda)^{2}} P_{0}+\frac{\lambda}{\mu}
$$

Hasil dari perhitungan rata-rata banyaknya kapal dalam system didapatkan untuk masing-masing dermaga dapat dilihat pada Tabel 6 .

Tabel 6. Rata-rata banyaknya kapal dalam system (Ls)

\begin{tabular}{l|ccccc}
\hline Nama Dermaga & $\begin{array}{c}\text { Arrival } \\
\text { Rate } \\
(\boldsymbol{\lambda})\end{array}$ & $\begin{array}{c}\text { Server } \\
(\mathbf{M})\end{array}$ & $\begin{array}{c}\text { Service } \\
\text { Rate } \\
(\boldsymbol{\mu})\end{array}$ & $\left(\mathbf{P}_{\mathbf{0}}\right)$ & $\begin{array}{c}(\mathbf{L s}) \\
\text { Kapal }\end{array}$ \\
\hline $\begin{array}{l}\text { Jamrud Utara dan } \\
\text { Barat }\end{array}$ & 1.882 & 5 & 0.303 & - & - \\
\hline Jamrud Selatan & 2.941 & 7 & 0.445 & $0.04 \%$ & $\mathbf{2 0 , 7 2 2}$ \\
\hline Berlian & 7.029 & 12 & 0.830 & $0.02 \%$ & $\mathbf{8 , 9 2 8}$ \\
\hline $\begin{array}{l}\text { Nilam Timur } \\
\text { (Multipurpose) }\end{array}$ & 1.735 & 5 & 0.412 & $0.91 \%$ & $\mathbf{7 , 6 5 7}$ \\
\hline Mirah & 2.559 & 5 & 0.600 & $0.83 \%$ & $\mathbf{8 , 0 6 9}$ \\
\hline
\end{tabular}

9) Rata-rata waktu menunggu dan dilayani menggunakan persamaan: [2]

$$
W_{S}=\frac{\mu(\lambda / \mu)^{M}}{(M-1) !(M \mu-\lambda)^{2}} P_{0}+\frac{1}{\mu}
$$

Hasil perhitungan rata-rata waktu menunggu dan dilayani didapatkan untuk masing-masing dermaga dapat dilihat pada Tabel 7.

Tabel 7. Rata-rata waktu menunggu dan

\begin{tabular}{l|ccccc}
\multicolumn{7}{c}{ dilayani } & $\begin{array}{c}\text { Arrival } \\
\text { Rate } \\
(\boldsymbol{\lambda})\end{array}$ & $\begin{array}{c}\text { Server } \\
(\mathbf{M})\end{array}$ & $\begin{array}{c}\text { Service } \\
\text { Rate } \\
(\boldsymbol{\mu})\end{array}$ & $\left(\mathbf{P}_{\mathbf{0}}\right)$ & $\begin{array}{c}(\mathbf{W s}) \\
\text { Hari }\end{array}$ \\
\hline $\begin{array}{l}\text { Jamrud Utara } \\
\text { dan Barat }\end{array}$ & 1.882 & 5 & 0.303 & - & - \\
\hline Jamrud Selatan & 2.941 & 7 & 0.445 & $0.04 \%$ & 7,046 \\
\hline Berlian & 7.029 & 12 & 0.830 & $0.02 \%$ & 1,270 \\
\hline $\begin{array}{l}\text { Nilam Timur } \\
\text { Multipurpose })\end{array}$ & 1.735 & 5 & 0.412 & $0.91 \%$ & 4,413 \\
\hline Mirah & 2.559 & 5 & 0.600 & $0.83 \%$ & 3,153 \\
\hline
\end{tabular}

10) Rata-rata kapal (unit) yang menunggu persamaan yang digunakan : [2]

$$
L_{q}=L_{s}-\frac{\lambda}{\mu}
$$

Hasil dari perhitungan rata-rata kapal (unit) yang menunggu didapatkan untuk masing-masing

\begin{tabular}{|c|c|c|c|c|}
\hline Nama Dermaga & $\begin{array}{l}\text { (Ls) } \\
\text { Kapal }\end{array}$ & $\begin{array}{c}\text { Arrival } \\
\text { Rate } \\
(\lambda)\end{array}$ & $\begin{array}{c}\text { Service } \\
\text { Rate } \\
(\boldsymbol{\mu})\end{array}$ & $\begin{array}{l}\left(\boldsymbol{L}_{q}\right) \\
\text { Kapal }\end{array}$ \\
\hline $\begin{array}{l}\text { Jamrud Utara dan } \\
\text { Barat }\end{array}$ & - & 1.882 & 0.303 & - \\
\hline Jamrud Selatan & 20,722 & 2.941 & 0.445 & 14,115 \\
\hline Berlian & 8,928 & 7.029 & 0.830 & 0,460 \\
\hline $\begin{array}{l}\text { Nilam Timur } \\
\text { (Multipurpose) }\end{array}$ & 7,657 & 1.735 & 0.412 & 3,441 \\
\hline Mirah & 8,069 & 2.559 & 0.600 & 3,807 \\
\hline
\end{tabular}
dermaga dapat dilihat pada Tabel 8.
Tabel 8. Rata-rata kapal (unit) yang menunggu

11) Rata-rata waktu menunggu persamaan yang digunakan: [2]

$$
W_{q}=W_{s}-\frac{1}{\mu}
$$

Hasil perhitungan rata-rata waktu menunggu dan dilayani didapatkan untuk masing-masing dermaga dapat dilihat pada Tabel 9.

Tabel 9. Rata-rata waktu menunggu

\begin{tabular}{l|cccc}
\hline Nama Dermaga & $\begin{array}{c}\left(\boldsymbol{W}_{\boldsymbol{s}}\right) \\
\text { Hari }\end{array}$ & $\begin{array}{c}\text { Arrival } \\
\text { Rate } \\
(\boldsymbol{\lambda})\end{array}$ & $\begin{array}{c}\text { Service } \\
\text { Rate } \\
(\boldsymbol{\mu})\end{array}$ & $\begin{array}{c}\left(\boldsymbol{W}_{\boldsymbol{q}}\right) \\
\text { Hari }\end{array}$ \\
\hline $\begin{array}{l}\text { Jamrud Utara dan } \\
\text { Barat }\end{array}$ & - & 1.882 & 0.303 & - \\
\hline Jamrud Selatan & 7,046 & 2.941 & 0.445 & 4,799 \\
\hline Berlian & 1,270 & 7.029 & 0.830 & 0,065 \\
\hline $\begin{array}{l}\text { Nilam Timur } \\
\text { (Multipurpose) }\end{array}$ & 4,413 & 1.735 & 0.412 & 1,983 \\
\hline Mirah & 3,153 & 2.559 & 0.600 & 1,488 \\
\hline
\end{tabular}

\subsection{Solusi Untuk Terminal Jamrud Utara dan Barat}

Solusi untuk Jamrud Utara Barat dapat dicari dengan melakukan simulasi penambahan channel sampai didapatkan nilai server utilization dibawah $100 \%$.

Tabel 10. Hasil analisis penambahan Channel Terminal Jamrud Utara dan Barat

\begin{tabular}{|c|c|c|c|}
\hline $\begin{array}{c}\text { Arrival Rate }(\boldsymbol{\lambda}) \\
\text { (unit/hari) }\end{array}$ & Server (M) & $\begin{array}{c}\text { Service } \\
\text { Rate }(\boldsymbol{\mu}) \\
\text { (unit/hari) }\end{array}$ & $\begin{array}{c}\text { Server } \\
\text { Utilization } \\
(\mathbf{p})\end{array}$ \\
\hline 1,882 & 5 & 0,303 & $124.44 \%$ \\
\hline 1,882 & 6 & 0,303 & $103.70 \%$ \\
\hline 1,882 & 7 & 0,303 & $\mathbf{8 8 . 8 8 \%}$ \\
\hline
\end{tabular}

Berdasarkan Tabel 10 dapat dilihat bahwa solusi agar nilai server utilization pada Jamrud Utara Barat dapat ditekan dibawah 100\% adalah menambah server sebanyak 2 channel sehingga banyak server menjadi 7 channel. Dengan penambahan 2 channel dapat dihitung kebutuhan penambahan panjang dermaga minimal sepanjang $366,125 \cong 400$ meter. 
Mengingat untuk menambah channel atau menambah panjang dermaga di Terminal Jamrud Utara dan Barat sulit untuk direalisasikan, maka solusi yang paling mungkin dapat diberikan agar Terminal Jamrud Utara dan Barat sebagai terminal general cargo internasional di Pelabuhan Tanjung Perak adalah dengan cara mengalihkan sebagian kapal untuk bersandar di pelabuhan sekitar misalnya ke Terminal Teluk Lamong dan Terminal Manyar BMS Gresik.

\subsection{Analisis Faktor-faktor yang Mempengaruhi Waktu Tunggu (Waiting Time) Kapal}

Metode analisis data yang digunakan dalam menentukan faktor yang mempengaruhi waiting time adalah metode analisis regresi berganda. Variabel dan indikator yang digunakan dalam analisis regresi berganda ini adalah sebagai berikut:

Tabel 11. Variabel dan indikator penelitian

\begin{tabular}{|c|c|c|c|}
\hline Konsep & Variabel & Indikator & Kode \\
\hline \multirow{15}{*}{$\begin{array}{c}\text { Waktu } \\
\text { Tunggu } \\
\text { Kapal } \\
\text { (Waiting } \\
\text { Time) } \\
\text { (Y) }\end{array}$} & \multirow{3}{*}{$\begin{array}{c}\text { Produktifitas } \\
\text { Bongkar } \\
\text { Muat }\left(\mathrm{X}_{1}\right)\end{array}$} & $\begin{array}{l}\text { Kinerja Tenaga Kerja } \\
\text { Bongkar Muat (TKBM) }\end{array}$ & $\mathrm{X}_{1.1}$ \\
\hline & & $\begin{array}{l}\text { Kinerja Peralatan } \\
\text { Bongkar Muat }\end{array}$ & $\mathrm{X}_{1.2}$ \\
\hline & & $\begin{array}{l}\text { Ketersediaan } \\
\text { Gudang/Lapangan } \\
\text { Penumpukan }\end{array}$ & $\mathrm{X}_{1.3}$ \\
\hline & \multirow{3}{*}{$\begin{array}{l}\text { Pelayanan } \\
\text { Dokumen } \\
\quad\left(\mathrm{X}_{2}\right)\end{array}$} & $\begin{array}{l}\text { Prosedur Pelayanan } \\
\text { Dokumen }\end{array}$ & $\mathrm{X}_{2.1}$ \\
\hline & & $\begin{array}{l}\text { Kinerja Pegawai di } \\
\text { Kantor Pelayanan }\end{array}$ & $\mathrm{X}_{2.2}$ \\
\hline & & Fasilitas Pelayanan (IT) & $\mathrm{X}_{2.3}$ \\
\hline & \multirow{3}{*}{$\begin{array}{l}\text { Kondisi } \\
\text { Alur } \\
\text { Pelayaran } \\
\left(\mathrm{X}_{3}\right)\end{array}$} & Pasang Surut & $\mathrm{X}_{3.1}$ \\
\hline & & Lalu lintas kapal & $\mathrm{X}_{3.2}$ \\
\hline & & Ukuran Kapal & $\mathrm{X}_{3.3}$ \\
\hline & \multirow{3}{*}{$\begin{array}{c}\text { Ketersedian } \\
\text { Dermaga } \\
\left(\mathrm{X}_{4}\right)\end{array}$} & Jumlah Dermaga & $\mathrm{X}_{4.1}$ \\
\hline & & Kondisi Fisik Dermaga & $\mathrm{X}_{4.2}$ \\
\hline & & Fasilitas Dermaga & $\mathrm{X}_{4.3}$ \\
\hline & \multirow{3}{*}{$\begin{array}{l}\text { Pelayanan } \\
\text { Pemanduan } \\
\quad\left(\mathrm{X}_{5}\right)\end{array}$} & $\begin{array}{l}\text { Jumlah Kapal Pandu dan } \\
\text { Kapal Tunda }\end{array}$ & $\mathrm{X}_{5.1}$ \\
\hline & & Jumlah Tenaga Pandu & $\mathrm{X}_{5.2}$ \\
\hline & & $\begin{array}{l}\text { Jarak antara Lego } \\
\text { Jangkar ke Dermaga }\end{array}$ & $\mathrm{X}_{5.3}$ \\
\hline
\end{tabular}

Berdasarkan Tabel 14 menunjukkan adanya hubungan yang signifikan secara positif antara X1 $\left(\mathrm{R}_{\mathrm{X} 1}=-0.566\right.$ dan $\left.\mathrm{p}=0.000\right), \mathrm{X} 2\left(\mathrm{R}_{\mathrm{X} 2}=\right.$ -0.433 dan $\mathrm{p}=0.000), \mathrm{X} 3\left(\mathrm{R}_{\mathrm{X} 3}=-0.424\right.$ dan $\mathrm{p}=0.000), \mathrm{X} 4\left(\mathrm{R}_{\mathrm{X} 4}=-0.587\right.$ dan $\left.\mathrm{p}=0.000\right), \mathrm{X} 5$ $\left(\mathrm{R}_{\mathrm{X} 5}=-0.518\right.$ dan $\left.\mathrm{p}=0.000\right)$, dengan $\mathrm{Y}$.

Berdasarkan Tabel 15 menunjukkan nilai koefisien korelasi ganda (Multiple R) sebesar 0.729 yang menyatakan besarnya derajat keeratan hubungan antara $\mathrm{X}_{1}, \mathrm{X}_{2}, \mathrm{X}_{3}, \mathrm{X}_{4}$, dan $\mathrm{X}_{5}$ terhadap $\mathrm{Y}$ mencapai 0.729 serta adanya hubungan yang kuat antara $\mathrm{X}_{1}, \mathrm{X}_{2}, \mathrm{X}_{3}, \mathrm{X}_{4}$, dan
$\mathrm{X}_{5}$ terhadap $\mathrm{Y}$ tersebut. Untuk nilai koefisien determinasi (r-square) menunjukkan sebesar 0.531 , yang menyatakan besarnya pengaruh dari $\mathrm{X}_{1}, \mathrm{X}_{2}, \mathrm{X}_{3}, \mathrm{X}_{4}$, dan $\mathrm{X}_{5}$ terhadap $\mathrm{Y}$. Artinya sebesar 53.1\% keragaman dari $\mathrm{Y}$ dipengaruhi oleh adanya faktor $X_{1}, X_{2}, X_{3}, X_{4}$, dan $X_{5}$. Sedangkan sisanya $46.9 \%$ ditentukan oleh faktor lain di luar variabel yang diteliti.

Maka persamaan regresi yang diperoleh adalah $Y=403.914-8.198 X_{1}-6.551 X_{2}-4.874$ $X_{3}-6.409 X_{4}-6.909 X_{5}$.

Tabel 12. Uji validitas instrumen penelitian

\begin{tabular}{|c|c|c|c|c|c|}
\hline \multirow[t]{2}{*}{ Variabel } & \multirow[t]{2}{*}{ Item } & \multicolumn{3}{|c|}{ Uji Validitas } & \multirow[t]{2}{*}{ Keputusan } \\
\hline & & $\mathbf{r}$ Hitung & Sign.(p) & $\mathbf{r}_{\text {Tabel }}$ & \\
\hline \multirow{3}{*}{$\begin{array}{c}\text { Produktifitas } \\
\text { Bongkar } \\
\text { Muat }\left(\mathrm{X}_{1}\right)\end{array}$} & $\mathrm{X} 1.1$ & 0.921 & 0.000 & 0,2199 & Valid \\
\hline & $\mathrm{X} 1.2$ & 0.870 & 0.000 & 0,2199 & Valid \\
\hline & $\mathrm{X} 1.3$ & 0.713 & 0.000 & 0,2199 & Valid \\
\hline \multirow{3}{*}{$\begin{array}{c}\text { Pelayanan } \\
\text { Dokumen } \\
\left(\mathrm{X}_{2}\right)\end{array}$} & $\mathrm{X} 2.1$ & 0.919 & 0.000 & 0,2199 & Valid \\
\hline & $\mathrm{X} 2.2$ & 0.741 & 0.000 & 0,2199 & Valid \\
\hline & $\mathrm{X} 2.3$ & 0.833 & 0.000 & 0,2199 & Valid \\
\hline \multirow{3}{*}{$\begin{array}{c}\text { Kondisi } \\
\text { Alur } \\
\text { Pelayaran } \\
\left(\mathrm{X}_{3}\right)\end{array}$} & X3.1 & 0.907 & 0.000 & 0,2199 & Valid \\
\hline & X 3.2 & 0.969 & 0.000 & 0,2199 & Valid \\
\hline & $\mathrm{X} 3.3$ & 0.961 & 0.000 & 0,2199 & Valid \\
\hline \multirow{3}{*}{$\begin{array}{c}\text { Ketersedian } \\
\text { Dermaga } \\
\left(\mathrm{X}_{4}\right)\end{array}$} & $\mathrm{X} 4.1$ & 0.920 & 0.000 & 0,2199 & Valid \\
\hline & $\mathrm{X} 4.2$ & 0.917 & 0.000 & 0,2199 & Valid \\
\hline & $\mathrm{X} 4.3$ & 0.908 & 0.000 & 0,2199 & Valid \\
\hline \multirow{3}{*}{$\begin{array}{c}\text { Pelayanan } \\
\text { Pemanduan } \\
\left(\mathrm{X}_{5}\right)\end{array}$} & $\mathrm{X} 5.1$ & 0.825 & 0.000 & 0,2199 & Valid \\
\hline & $\mathrm{X} 5.2$ & 0.814 & 0.000 & 0,2199 & Valid \\
\hline & $\mathrm{X} 5.3$ & 0.811 & 0.000 & 0,2199 & Valid \\
\hline
\end{tabular}

Tabel 13. Uji reliabilitas instrumen penelitian

\begin{tabular}{ccc}
\hline Variabel & $\begin{array}{c}\text { Alpha } \\
\text { Cronbach }\end{array}$ & Keterangan \\
\hline $\begin{array}{c}\text { Produktifitas Bongkar Muat } \\
\left(\mathrm{X}_{1}\right)\end{array}$ & 0.792 & $\begin{array}{c}\text { Tingkat kehandalan } \\
\text { tinggi }\end{array}$ \\
\hline $\begin{array}{c}\text { Waktu Pelayanan Dokumen } \\
\left(\mathrm{X}_{2}\right)\end{array}$ & 0.785 & $\begin{array}{c}\text { Tingkat kehandalan } \\
\text { tinggi }\end{array}$ \\
\hline Kondisi Alur Pelayaran $\left(\mathrm{X}_{3}\right)$ & 0.942 & $\begin{array}{c}\text { Tingkat kehandalan } \\
\text { sangat tinggi }\end{array}$ \\
\hline Ketersedian Dermaga $\left(\mathrm{X}_{4}\right)$ & 0.903 & $\begin{array}{c}\text { Tingkat kehandalan } \\
\text { sangat tinggi }\end{array}$ \\
\hline Pelayanan Pemanduan $\left(\mathrm{X}_{5}\right)$ & 0.752 & $\begin{array}{c}\text { Tingkat kehandalan } \\
\text { tinggi }\end{array}$ \\
\hline
\end{tabular}

Tabel 14. Uji korelasi product momen Pearson

\begin{tabular}{|c|c|c|c|c|}
\hline \multicolumn{2}{|l|}{ Variabel } & \multicolumn{2}{|l|}{ Uji korelasi } & \multirow[t]{2}{*}{ Kesimpulan } \\
\hline & & Korelasi (r) & $\begin{array}{l}\text { Sig. } \\
\text { (p) }\end{array}$ & \\
\hline \multirow{5}{*}{$\mathbf{Y}$} & $\mathrm{X}_{1}$ & -0.566 & 0.000 & $\begin{array}{c}\text { Ada hubungan yang signifikan } \\
\text { antara } \mathrm{X}_{1} \text { dan } \mathrm{Y}\end{array}$ \\
\hline & $\mathrm{X}_{2}$ & -0.433 & 0.000 & $\begin{array}{c}\text { Ada hubungan yang signifikan } \\
\text { antara } \mathrm{X}_{2} \text { dan } \mathrm{Y}\end{array}$ \\
\hline & $\mathrm{X}_{3}$ & -0.424 & 0.000 & $\begin{array}{c}\text { Ada hubungan yang signifikan } \\
\text { antara } \mathrm{X}_{3} \text { dan } \mathrm{Y}\end{array}$ \\
\hline & $\mathrm{X}_{4}$ & -0.587 & 0.000 & $\begin{array}{c}\text { Ada hubungan yang signifikan } \\
\text { antara } \mathrm{X}_{4} \text { dan } \mathrm{Y}\end{array}$ \\
\hline & $\mathrm{X}_{5}$ & -0.518 & 0.000 & $\begin{array}{c}\text { Ada hubungan yang signifikan } \\
\text { antara } \mathrm{X}_{5} \text { dan Y }\end{array}$ \\
\hline
\end{tabular}

Keterangan: X1= Produktifitas Bongkar Muat, X2= Pelayanan Dokumen, X3= Kondisi Alur Pelayaran, X4= Ketersedian Dermaga, X5= Pelayanan Pemanduan, $\mathbf{Y}=$ Waktu Tunggu Kapal (Waiting Time) 
Tabel 15. Hasil analisis regresi

\begin{tabular}{|c|c|c|c|c|c|c|}
\hline Variabel & $\begin{array}{c}\text { Koefisien } \\
\text { regresi (b) }\end{array}$ & $\begin{array}{c}\text { Std. } \\
\text { Error }\end{array}$ & Beta & $\mathbf{T}_{\text {hitung }}$ & Sig. & Keterangan \\
\hline Konstanta & 403.914 & 40.743 & & 9.914 & 0.000 & Signifikan \\
\hline $\mathrm{X}_{1}$ & -8.198 & 3.875 & -0.214 & -2.116 & 0.038 & Signifikan \\
\hline $\mathrm{X}_{2}$ & -6.551 & 3.149 & -0.181 & -2.080 & 0.041 & Signifikan \\
\hline $\mathrm{X}_{3}$ & -4.874 & 2.180 & -0.199 & -2.236 & 0.028 & Signifikan \\
\hline $\mathrm{X}_{4}$ & -6.409 & 3.002 & -0.226 & -2.135 & 0.036 & Signifikan \\
\hline $\mathrm{X}_{5}$ & -6.909 & 3.081 & -0.221 & -2.243 & 0.028 & Signifikan \\
\hline $\begin{array}{l}\mathrm{R} \text { (Multi) } \\
\mathrm{R} \text { Square } \\
\mathrm{R} \text { Square } \\
\mathrm{F} \text { hitung } \\
\mathrm{F} \text { tabel } \\
\text { Sign. F } \\
\mathrm{t} \text { tabel } \\
\alpha \\
\end{array}$ & $\begin{array}{l}\text { (Adjusted) } \mathrm{R}) \\
\text { (Adjo }\end{array}$ & $\begin{array}{l}= \\
= \\
= \\
= \\
= \\
= \\
= \\
=\end{array}$ & $\begin{array}{l}, 729 \\
, 531 \\
, 499 \\
6.749 \\
\text { df regres } \\
, 000 \\
, 05 / 2,7 \\
, 05\end{array}$ & $\begin{array}{l}\text { df residu } \\
=1.993\end{array}$ & $\mathrm{al})=(5$ & $74)=2.338$ \\
\hline
\end{tabular}

Tabel 16. Perhitungan sumbangan efektif

\begin{tabular}{ccccc}
\hline Variabel & $\mathbf{R}$ & Beta & Perhitungan & SE \\
\hline $\mathrm{X}_{1}$ & -0.566 & -0.214 & $-0.566 \mathrm{x}-0.214 \mathrm{x} 100$ & $12.11 \%$ \\
\hline $\mathrm{X}_{2}$ & -0.433 & -0.181 & $-0.433 \mathrm{x}-0.181 \times 100$ & $7.83 \%$ \\
\hline $\mathrm{X}_{3}$ & -0.424 & -0.199 & $-0.424 \mathrm{x}-0.199 \times 100$ & $8.46 \%$ \\
\hline $\mathrm{X}_{4}$ & -0.587 & -0.226 & $-0.587 \mathrm{x}-0.226 \times 100$ & $13.25 \%$ \\
\hline $\mathrm{X}_{5}$ & -0.518 & -0.221 & $-0.518 \mathrm{x}-0.221 \mathrm{x} 100$ & $11.43 \%$ \\
\hline \multicolumn{5}{c}{ Total Sumbangan Efektif } \\
\hline \multicolumn{5}{c}{$53.09 \%$} \\
\hline
\end{tabular}

Berdasarkan Tabel 16, variabel Ketersedian Dermaga (X4) menunjukkan sumbangan efektif yang paling besar (dominan) yaitu sebesar $13.25 \%$, diikuti kemudian oleh pengaruh dari Produktifitas Bongkar Muat (X1) dengan sumbangan efektif sebesar $12.11 \%$.

\subsection{Strategi Perbaikan untuk Menurunkan Waktu Tunggu (Waiting Time) Kapal di Pelabuhan Tanjung Perak}

SWOT adalah identitas berbagai factor secara sistematis untuk merumuskan strategi pelayanan.[4]

1) Penentuan Faktor-Faktor Internal dan

Eksternal

Dalam analisa SWOT IFAS EFAS dilakukan survey lingkungan dengan mengumpulkan berbagai informasi tentang strategi mengurangi waktu tunggu kapal dipelabuhan. Pengumpulan informasi dilakukan dengan cara wawancara langsung kepada pihak-pihak yang dianggap berkompeten tentang pelabuhan, observasi lapangan, dari hasil analisis antrian serta analisis korelasi dan regresi faktor-faktor yang mempengaruhi waktu tunggu kapal. Kemudian hasil survey lingkungan tersebut direkapitulasi dan diolah menjadi faktor internal dan faktor ekternal.

\section{2) Perhitungan Penentuan Pembobotan Skor} SWOT.

Setelah diketahui dan dipetakan faktor-faktor internal dan eksternal maka dilakukan pembagian kuesioner. Dari pemetaan SWOT bobot dan rating ditentukan berdasar pada isian kuisioner [6]. Perhitungan pembobotan skor SWOT EFAS dan IFAS terlihat pada Tabel 18 dan Tabel 18.

\section{3) Matriks SWOT}

Hasil perhitungan bobot dan skor IFAS dan EFAS, faktor-faktor dari strategi tersebut akan diolah ke dalam matrik SWOT untuk merumuskan strategi yang nanti akan dipakai dalam rangka mengurangi waktu tunggu kapal (waiting time) Pelabuhan Tanjung Perak.

\section{4) Diagram Analisa SWOT}

Dari perhitungan nilai total kekuatan - total kelemahan dan nilai total peluang - total ancaman, maka akan di lakukan plot ke diagram kartesius untuk mendapatkan strategi yang akan digunakan.

Dari Gambar 7 yang didasarkan pada perhitungan $S W O T$ IFAS dan EFAS $S>O$, yakni kekuatan lebih besar dari pada peluang yang ada, dimana arah kebijakannya adalah rapid growth strategy yang berarti pertumbuhan peran yang dilaksanakan dapat dilakukan dengan cepat (strategi agresif). Strategi tersebut dapat dilakukan untuk menurunkan waktu tunggu (waiting time) kapal di Pelabuhan Tanjung Perak yang diuraikandengan cara sebagai berikut :

a. Memaksimalkan kinerja Tenaga Kerja Bongkar Muat (TKBM)

b. Mengalihkan kapal ke pelabuhan sekitar misalnya Terminal Teluk Lamong dan Terminal Manyar BMS Gresik

c. Meningkatkan pelayanan dan prosedur pengurusan dokumen di pelabuhan;

d. Mengembangkan Alur Pelayaran Surabaya(APBS) untuk merevitalisasi alur pelayaran dan kolam pelabuhan

e. Menerapkan regulasi tentang kepelabuhanan dengan benar

f. Memaksimalkan tenaga pandu yang ada. 
Tabel 18. Hasil Perhitungan Bobot dan Skor IFAS

\begin{tabular}{|c|c|c|c|c|c|}
\hline \multirow[t]{2}{*}{ NO } & $\begin{array}{l}\text { FAKTOR - FAKTOR } \\
\text { STRATEGI INTERNAL }\end{array}$ & \multirow[t]{2}{*}{ Вовот } & \multirow{2}{*}{$\begin{array}{l}\text { BOBOT } \\
\text { RELATIF }\end{array}$} & \multirow[t]{2}{*}{ RATING } & \multirow[t]{2}{*}{ SKOR } \\
\hline & INDIKATOR KEKUATAN & & & & \\
\hline \multirow[t]{2}{*}{1} & Kinerja Tenaga Kerja & & & & \\
\hline & $\begin{array}{l}\text { Bongkar Muat (TKBM) } \\
\text { sangat baik; }\end{array}$ & 3,4 & 0,12 & 2,70 & 0,33 \\
\hline 2 & $\begin{array}{l}\text { Prosedur pelayanan } \\
\text { dokumen yang } \\
\text { sederhana; }\end{array}$ & 3,5 & 0,13 & 2,70 & 0,34 \\
\hline 3 & Klusterisasi dermaga & 4 & 0,14 & 2,50 & 0,36 \\
\hline 4 & $\begin{array}{l}\text { Lalu lintas kapal yang } \\
\text { lancar }\end{array}$ & 3,2 & 0,12 & 3,00 & 0,35 \\
\hline 5 & $\begin{array}{l}\text { Jumlah tenaga pandu } \\
\text { yang memadai; }\end{array}$ & 3,8 & 0,14 & 2,10 & 0,29 \\
\hline \multicolumn{2}{|c|}{ Jumlah Indikator Kekuatan } & 17,9 & 0,65 & & 1,67 \\
\hline \multirow[t]{2}{*}{ NO } & $\begin{array}{l}\text { FAKTOR - FAKTOR } \\
\text { STRATEGI INTERNAL }\end{array}$ & \multirow[t]{2}{*}{ Вовот } & \multirow{2}{*}{$\begin{array}{l}\text { BOBOT } \\
\text { RELATIF }\end{array}$} & \multirow[t]{2}{*}{ RATING } & \multirow[t]{2}{*}{ SKOR } \\
\hline & INDIKATOR KELEMAHAN & & & & \\
\hline 1 & $\begin{array}{l}\text { Kurangnya ketersedian } \\
\text { dermaga }\end{array}$ & 1,80 & 0,06 & 3,70 & 0,24 \\
\hline \multirow[t]{2}{*}{2} & Kurang memadainya & & & & \\
\hline & $\begin{array}{l}\text { Fasilitas Pelayanan dan } \\
\text { informasi teknologi (IT); }\end{array}$ & 2,10 & 0,08 & 3,10 & 0,24 \\
\hline 3 & $\begin{array}{l}\text { Kedalaman alur pelayaran } \\
\text { dan kolam Pelabuhan } \\
\text { Masih Kurang }\end{array}$ & 1,60 & 0,06 & 3,50 & 0,20 \\
\hline 4 & $\begin{array}{l}\text { Kurangnya jumlah kapal } \\
\text { pandu dan kapal tunda. }\end{array}$ & 2,30 & 0,08 & 3,70 & 0,31 \\
\hline 5 & $\begin{array}{l}\text { Peralatan Bongkar Muat } \\
\text { yang tidak sesuai dengan } \\
\text { peruntukan }\end{array}$ & 2,00 & 0,07 & 3,50 & 0,25 \\
\hline \multicolumn{2}{|c|}{ Jumlah Indikator Kelemahan } & 9,80 & 0,35 & & \multirow{3}{*}{$\begin{array}{l}1,24 \\
2,91\end{array}$} \\
\hline & Total Faktor Internal & 27,7 & 1 & & \\
\hline \multicolumn{2}{|r|}{ Kekuatan - kelemahan } & & 0,43 & & \\
\hline
\end{tabular}

\section{KESIMPULAN DAN SARAN}

\subsection{Kesimpulan}

Berdasarkan hasil analisa dapat ditarik kesimpulan antara lain:

1. Rata-rata waktu tunggu kapal (waiting time) Pelabuhan Tanjung Perak pada 5 terminal diketahui: Terminal Jamrud Utara dan Barat adalah 46,20 jam, Terminal Jamrud Selatan 42,61 jam, Terminal Berlian 29,94 jam, Terminal Nilam Timur (multipurpose) adalah 41,77 jam dan Terminal Mirah adalah 29,94 jam.

Kerakteristik antrian di Pelabuhan Tanjung Perak pada Terminal Jamrud Utara dan Barat memiliki rata-rata waktu kedatangan 1,882 kapal/hari, Terminal Jamrud Selatan 2,941 hari, Terminal Berlian 7,029 kapal/hari, Terminal Nilam Timur (multipurpose) 1,735
Tabel 18. Hasil Perhitungan Bobot dan Skor EFAS

\begin{tabular}{|c|c|c|c|c|c|}
\hline NO & $\begin{array}{l}\text { FAKTOR - FAKTOR } \\
\text { STRATEGI EKSTERNAL } \\
\text { INDIKATOR PELUANG }\end{array}$ & ВОВот & $\begin{array}{l}\text { ВОВОт } \\
\text { RELATIF }\end{array}$ & RATING & SKOR \\
\hline 1 & $\begin{array}{l}\text { Beroperasinya Terminal } \\
\text { Teluk Lamong dan } \\
\text { Terminal Manyar BMS } \\
\text { Gresik }\end{array}$ & 3,60 & 0,12 & 2,50 & 0,31 \\
\hline 2 & $\begin{array}{l}\text { Meningkatnya volume } \\
\text { bongkar }\end{array}$ & 3,60 & 0,12 & 2,60 & 0,32 \\
\hline 3 & $\begin{array}{l}\text { Kebijakan pemerintah } \\
\text { tentang Kepelabuhanan; }\end{array}$ & 3,50 & 0,12 & 2,40 & 0,29 \\
\hline 4 & $\begin{array}{l}\text { Adanya Proyek } \\
\text { Pendalaman Alur } \\
\text { Pelayaran Barat } \\
\text { Surabaya (APBS); }\end{array}$ & 3,80 & 0,13 & 2,60 & 0,34 \\
\hline 5 & $\begin{array}{l}\text { Jumlah kunjungan kapal } \\
\text { mengalami peningkatan } \\
\text { yang signifikan. }\end{array}$ & 4,00 & 0,14 & 2,10 & 0,29 \\
\hline Jun & mlah Indikator Peluang & 18,50 & 0,63 & & 1,54 \\
\hline NO & $\begin{array}{l}\text { FAKTOR - FAKTOR } \\
\text { STRATEGI EKSTERNAL } \\
\text { INDIKATOR } \\
\text { ANCAMAN }\end{array}$ & ВОВОт & $\begin{array}{l}\text { BOBOT } \\
\text { RELATIF }\end{array}$ & RATING & SKOR \\
\hline 1 & $\begin{array}{l}\text { Adanya pendangkalan } \\
\text { atau sedimentasi pada } \\
\text { Alur Pelayaran dan } \\
\text { Kolam Pelabuhan; }\end{array}$ & 1,70 & 0,06 & 3,80 & 0,22 \\
\hline 2 & $\begin{array}{l}\text { Adanya kebijakan terkait } \\
\text { perdagangan; }\end{array}$ & 2,50 & 0,09 & 3,50 & 0,30 \\
\hline 3 & $\begin{array}{l}\text { Kurang disiplinnya } \\
\text { pengguna jasa terhadap } \\
\text { prosedur penyandaran } \\
\text { kapal; }\end{array}$ & 2,20 & 0,08 & 3,50 & 0,26 \\
\hline 4 & $\begin{array}{l}\text { Faktor cuaca yang tidak } \\
\text { menentu; }\end{array}$ & 2,10 & 0,07 & 3,30 & 0,24 \\
\hline 5 & $\begin{array}{l}\text { Tingkat pemakaian } \\
\text { dermaga yang cukup } \\
\text { tinggi (BOR) }\end{array}$ & 2,30 & 0,08 & 3,30 & 0,26 \\
\hline Jum & nlah Indikator Ancaman & 10,80 & 0,37 & & 1,28 \\
\hline & Total Faktor Eksternal & 29,30 & 1,00 & & 2,81 \\
\hline & Peluang - Ancaman & & 0,26 & & \\
\hline
\end{tabular}

kapal/hari dan Terminal Mirah 2,559 $\mathrm{kapal} / \mathrm{hari}$. Rata-rata waktu pelayanan (service rate) Terminal Jamrud Utara dan Barat sebesar 0,303 hari/kapal, Terminal Jamrud Selatan (service rate) 0,445 hari/kapal, Terminal Berlian (service rate) 0,830 hari/kapal, Terminal Nilam Timur (service rate) 0,412 hari/kapal, kemudian Terminal Mirah sebesar (service rate) 0,600 hari/kapal. Pola antrian pada Terminal Jamrud Selatan dengan nilai $(\rho)$ $=94.40 \%, P_{0}=0.04 \%, L_{s}=20.722 \mathrm{kapal}, W_{s}=$ 7.046 hari, $L_{q}=14.115$ kapal, $W_{q}=4.799$ hari, Terminal Berlian $(\rho)=70.56 \%, P_{0}=0.02 \%$, $L_{S}=8.928$ kapal, $W_{s}=1.270$ hari, $L_{q}=0.460$ kapal, $W_{q}=0.065$ hari, Terminal Nilam Timur (Multipurpose) $(\rho)=84.31 \%, P_{0}=0.91 \%, L_{s}=$ $7.657 \mathrm{kapal}, W_{s}=4.413$ hari, $L_{q}=3.441 \mathrm{kapal}$, 
$W_{q}=1.983$ hari, Terminal Mirah $(\rho)=85.24 \%$, $P_{0}=0.83 \%, L_{s}=8.069$ kapal, $W_{s}=3.153$ hari, $L_{q}=3.807 \mathrm{kapal}, W_{q}=1.488$ hari. Untuk fasilitas Terminal Jamrud Utara dan Barat sudah tidak memadai. Solusi terbaik untuk menurunkan tingkat penggunaan dermaga $(\rho)$ adalah dengan cara mengalihkan sebagian kapal ke Terminal Teluk Lamong.

2. Faktor yang mempengaruhi waktu tunggu kapal (waiting time) Pelabuhan Tanjung Perak dari 5 variabel dengan 15 indikator, diperoleh dari semua variabel berpengaruh terhadap waktu tunggu kapal dengan model regresi yang didapatkan yaitu $\mathrm{Y}=403.914-8.198 \mathrm{X}_{1}$ $6.551 \mathrm{X}_{2}-4.874 \mathrm{X}_{3}-6.409 \mathrm{X}_{4}-6.909 \mathrm{X}_{5}$. Variabel Ketersedian Dermaga (X4) menunjukkan sumbangan efektif yang paling besar (dominan) yaitu sebesar 13.25\%, diikuti kemudian oleh pengaruh dari Produktifitas Bongkar Muat (X1) dengan sumbangan efektif sebesar $12.11 \%$. Selanjutnya dari hasil perhitungan tersebut dapat diketahui bahwa $\mathrm{X}_{1}, \mathrm{X}_{2}, \mathrm{X}_{3}, \mathrm{X}_{4}$, dan $\mathrm{X}_{5}$ ternyata mampu memberikan sumbangan efektif total sebesar $53.09 \%$ terhadap Y.

3. Strategi dalam mengurangi waktu tunggu (waiting time) kapal di Pelabuhan Tanjung Perak yaitu dengan memaksimalkan kinerja Tenaga Kerja Bongkar Muat (TKBM), mengalihkan kapal untuk bersandar di pelabuhan sekitar misalnya Terminal Teluk Lamong dan Terminal Manyar BMS Gresik serta meningkatkan pelayanan dan prosedur pengurusan dokumen di pelabuhan untuk menanggulangi kenaikan arus barang.

Tabel 19. Matrik SWOT strategi mengurangi waktu tunggu kapal (waiting time) Pelabuhan Tanjung Perak

\begin{tabular}{|c|c|c|}
\hline EFAS & $\begin{array}{ll}\text { Kekuatan (Strength) } \\
\text { 1. } \\
\text { Perbaikan Kinerja Tenaga Kerja Bongkar } \\
\text { 2. Prosia); } \\
\text { Sederhana; } \\
\text { 3. Klusterisasi dermaga; } \\
\text { 4. Lalu lintas kapal yang lancar; } \\
\text { 5. Jumlah tenaga pandu yang memadai; }\end{array}$ & $\begin{array}{l}\text { Kelemahan (Weakness) } \\
\text { 1. Kurangnya ketersedian dermaga; } \\
\text { 2. Kurang memadainya Fasilitas Pelayanan } \\
\text { dan informasi teknologi (IT); } \\
\text { 3. Kedalaman Alur pelayaran dan Kolam } \\
\text { Pelabuhan Masih Kurang; } \\
\text { 4. Kurangnya jumlah kapal pandu dan kapal } \\
\text { tunda. } \\
\text { 5. Peralatan Bongkar Muat yang tidak sesuai } \\
\text { dengan peruntukan; }\end{array}$ \\
\hline $\begin{array}{ll}\text { Peluang (Opportunity) } \\
\text { 1. } & \begin{array}{l}\text { Beroperasinya Terminal } \\
\text { Teluk Lamong dan Terminal }\end{array} \\
\text { Manyar BMS Gresik; } \\
\text { 2. Meningkatnya } \\
\text { bongkar dan muat; } \\
\text { 3. } \begin{array}{l}\text { Kebijakan pemerintah tentang } \\
\text { Kepelabuhanan; }\end{array} \\
\text { 4. Adanya pengembangan Alur } \\
\text { Pelayaran Barat Surabaya } \\
\text { (APBS); kunjungan kapal } \\
\text { Jumlah kun } \\
\text { mengalami peningkatan yang } \\
\text { signifikan. }\end{array}$ & 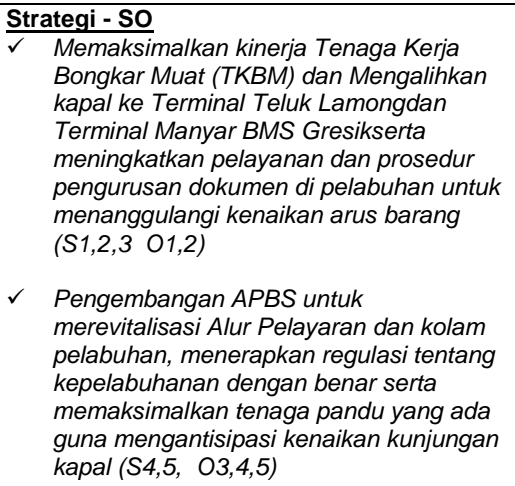 & 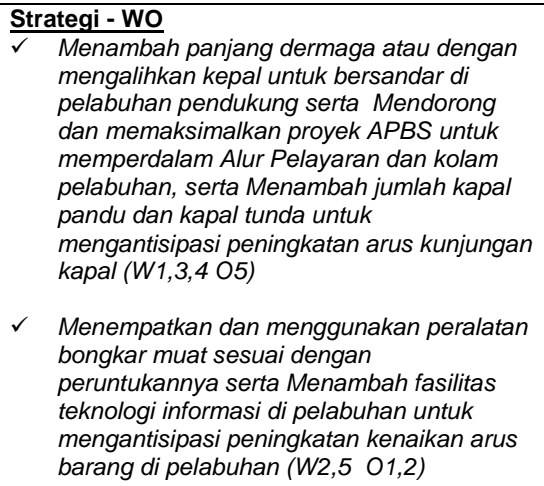 \\
\hline $\begin{array}{l}\text { Ancaman (Threat) } \\
\text { 1. Adanya pendangkalan atau } \\
\text { sedimentasi pada Alur dan } \\
\text { Kolam Pelabuhan; } \\
\text { 2. Adanya kebijakan terkait } \\
\text { perdagangan; } \\
\text { 3. Kurang disiplinnya pengguna } \\
\text { jasa terhadap prosedur } \\
\text { penyandaran kapal; } \\
\text { 4. Faktor cuaca yang tidak } \\
\text { menentu; } \\
\text { 5. Tingkat pemakaian dermaga } \\
\text { yang cukup tinggi (BOR) }\end{array}$ & 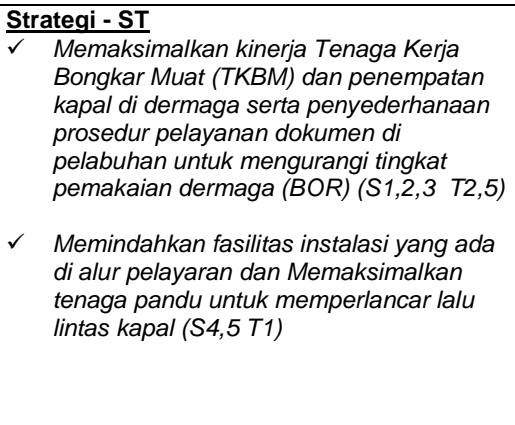 & 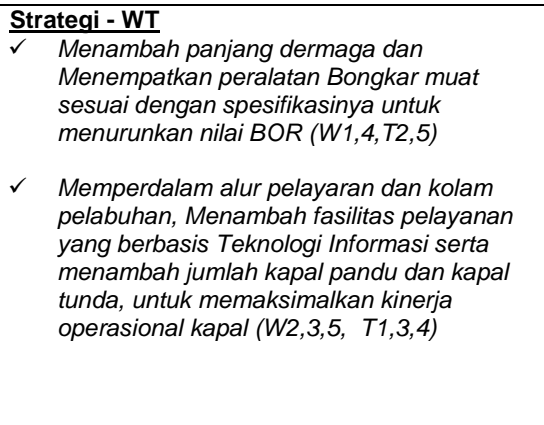 \\
\hline
\end{tabular}




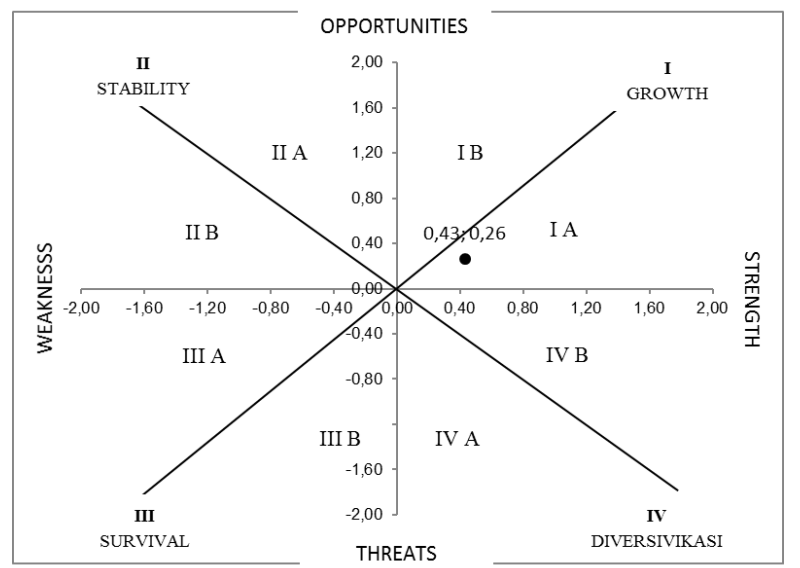

Gambar 7. Hasil analisis diagram SWOT

4. Strategi berikutnya adalah dengan mengembangkan Alur Pelayaran Barat Surabaya (APBS) untuk merevitalisasi alur pelayaran dan kolam pelabuhan, menerapkan regulasi tentang kepelabuhanan dengan benar serta memaksimalkan tenaga pandu yang ada guna mengantisipasi kenaikan kunjungan kapal.

\subsection{Saran}

1. Dari hasil analisa variabel $X_{1}, X_{2}, X_{3}, X_{4}$, dan $\mathrm{X}_{5}$ terhadap $\mathrm{Y}$ (waktu tunggu) didapat sumbangan efektif sebesar $53 \%$ yang membuktikan bahwa masih ada $47 \%$ variabel yg belum ditentukan. hal ini dapat digunakan sebagai bahan acuan untuk penelitian selanjutnya.

2. Perlunya peningkatan jalinan koordinasi antara semua pihak yang berkepentingan di Pelabuhan Tanjung Perak terkait dengan pelayanan kapal dan barang sehingga terselenggara pelayanan yang optimal bagi masyarakat pengguna jasa angkutan penyeberangan.
5. DAFTAR PUSTAKA

[1] Lasse, D. A. (2012). Manajemen Kepelabuhanan. Jakarta: NIKA.

[2] Heyzer, J. H., \& Render, B. (2009). Operation Management, Volume 1. Pennsylvania State University: Pearson Prentice Hall.

[3] PT. Pelabuhan Indonesia (Persero). (2009). Pengoperasian Pelabuhan - Referensi Kepelabuhanan Seri 6 . Jakarta: PT. Pelabuhan Indonesia (Persero).

[4] Rangkuti, F. (2005). Analisa SWOT Teknik Membedah Kasus Bisnis. Jakarta: PT. Gramedia Pustaka.

[5] Siregar, S. (2013). Metode Penelitian Kuantitatif. Jakarta: Kencana Prenada Media Group.

[6] Umar, H. (2005). Strategic Management in Action Cetakan Kelima. Jakarta: Gramedia Pustaka Utama.

[7] Zaiontz, C. (2014). Poisson Dstribution. Diambil kembali dari Real Statistics Using Excel: http://www.real-statistics.com/binomial-andrelated-distributions/poisson-distribution/ 